\title{
Goodbye Hippocrates?
}

\author{
Michael Ashby
}

Published online: 29 July 2021

(C) Journal of Bioethical Inquiry Pty Ltd. 2021

Keywords Hippocrates - History of medicine · Islamic bioethics $\cdot$ Transplant $\cdot$ Organ sales $\cdot$ Hunger strike $\cdot$ Consent of minors $\cdot$ Palliative care $\cdot$ Voluntary assisted dying · Infertility · Dissection · Access to experimental therapies $\cdot$ Failed tubal ligation

It is still probably widely believed that a new doctor "takes" the Hippocratic "oath," and that somehow this is the basis of public ethical protection, that in the swearing of an oath the profession is restrained and safe. The idea that this apparently time-honoured practice should summarize and guide the ethics of medical practice in the twenty-first century is fanciful, and few medical schools now have such a ceremony, requirement, or rite of passage at graduation that includes such an oath.

Fiddes and Komesaroff (2021) analyse the first aphorism and trace its textual history. While life may be short and the art long, these authors conclude that the second part of this famous passage that requires the patient to effectively do what he or she is told by the doctor, should be scrapped as paternalistic and out of touch with today's world and community expectations. Whilst there is much to commend

M. Ashby $(\bowtie)$

Cancer, Chronic Disease and Sub-Acute Stream, Royal Hobart Hospital, Tasmanian Health Service, School of Medicine, University of Tasmania, Royal Hobart Hospital, Hobart, TAS 7000, Australia e-mail: michael.ashby@ths.tas.gov.au this viewpoint, it is nonetheless surely true that if you embark on a course of treatment or an intervention of some sort, it is indeed wise to follow instructions, and that the contract is two-way. It is also clear that at a time when holism is being discovered, or re-discovered as the case may be, the patient's will needs to be engaged and active patient participation is a central pathway to success for most therapeutic journeys. The Hippocratic writings are clearly out of date, and despite their prominence in the teachings of, for example, modern medical education pioneer William Osler, they can now be safely abandoned as sexist, paternalistic, and elitist. It is interesting that medicine has for so long sought to derive a marching tune from its own history, the virtuous practitioner passing down his art to the venerating pupil, akin to the mason passing on the secrets of building, from one generation to another. The Hippocratic tradition derives from a time when poisoning was common, and doctors had the most knowledge about the agents available, hence the interdict on provision of poisons. The complete prohibition on any causal contribution to patient death is often cited in assisted dying debates, and no doubt this will continue, as is the case for abortion too. Adages such as "first do no harm" and many of those in the Hippocratic canon, have little viability in the era of therapeutic ratios, risk/benefit analysis, and the use of toxic treatments or massive surgery to attempt cure at the brink of possibility. It is surely important for the public to know that it is protected by both ethics and law, in a far more 
sophisticated way than any oath could do, and that in the age of transparency, accountability, and community engagement, that they themselves help to set the standards.

McLachlan (2021) considers the selling and altruistic donation of transplant organs. He argues for caution in the use of the concept of exploitation in these discussions and concludes that there is less of a moral difference between these two donations than many would think, including the legal distinction.

Winters, Owens, and Winters (2021), based in Otago, New Zealand, analyse decision-making pathways for a fourteen year old minor hunger striker in Australian offshore refugee detention. They put forward a "composite" case that effectively means that it is a fictitious case based on the facts drawn from more than one actual case. They pay considerable attention to the evaluation of so-called "Gillick" competence, with reference to neuropsychiatric and testing data, as well as child development theories, to conclude that many young people at or around fourteen have similar reasoning powers to those who have reached eighteen. The bigger issue of parental disagreement, and political protest as the motivation for sewing her lips together, make this a truly hard case with regard to healthcare duties in this awful environment: whether to remove the stitches and institute feeding against the will of a young person condemned to incarceration without obvious end in sight or stand back and allow her to proceed with the hunger strike and possibly die.

Perez-Bret, Jaman-Mewes, and Quiroz (2021) showed a couple of videoclips to health students in palliative care settings in Madrid, featuring Cameron Duncan, a young man suffering from terminal cancer (DFK6498 and Strike Zone). The exercise showed positive engagement and empathy amongst the students in the study. This confirms anecdotal experience that showing young people age-appropriate videos about death, dying, loss, and grief topics can be very rewarding and may access emotional spaces that cannot be so easily reached with the use of stories of older people.

Australia is presently seeing progressive legislation across its states to allow assisted dying (Victoria, Western Australia, Tasmania, and in progress in South Australia and Queensland). All the bills tabled have been based on self-administration models from Oregon and Washington states in the
United States, and like nearly all such legislation, there are clauses that restrict access to those who have progressive fatal illnesses and suffering that cannot be relieved. Hempton and Mills (2021) critique the restrictions imposed by the Voluntary Assisted Dying Act 2017 (Vic), the legislation in this Australian state that permits assisted dying only for a person who is already dying. It is clear from Canada and the Netherlands, that there are moves to gain access for those who are not dying and those who are "tired of life." This will no doubt please and horrify those who predicted slippery slopes, but it now seems likely that these early very restrictive provisions will gradually be modified to allow access for people who have high chronic disease burdens but are not imminently dying, especially in very old age, and the issue of dementia and advance direction will demand attention at some future time. For now, these authors feel that this very restrictive prognostic access gives excessive power to doctors and diminishes true autonomous choice in dying. Haining, Keogh, and Gillam (2021) conducted semi-structured interviews with seventeen health professionals in Victoria before the implementation of VAD, to further understand conscientious objection (CO), which was thought to be a significant barrier to public access. They found a greater diversity of personal and professional objections than expected and a number who objected to the specific Victorian legislation rather than to VAD itself.

Courtwright et al. (2021) from the Optimum Care Committee, Massachusetts General Hospital, and the Rand Corporation have studied the relationship between their ethics consultation and transplant teams. In this mature ethics consultation setting, it is noted that only a very small number of transplant cases are referred for an ethics consultation, 6.8 per cent of referrals, $60 / 880$ over a ten-year period. These referrals were more likely to be made by a nurse and usually concerned treatment issues before and/or after transplantation and rarely concerned resource allocation in that setting.

Assisted reproduction has benefited from astounding scientific advances but Stuhmcke (2021) writes that in the Australian medico-legal context, there is now an over-medicalization, and that infertility the "disease" should be replaced by a broader understanding of the desire to have children. This includes fostering, adoption, and childlessness as a 
range of options to replace the binary fertile/infertile dichotomization.

Stephan and Fisk (2021) point out that anatomy and dissection are often dealt with in a sensationalist way in the media and arts, with the effect of diminishing the dignity of those who donate their bodies for this worthy cause. The authors trace the gruesome history of dissection from medieval Europe and Britain, with its original purposes in philosophy and understanding of God's creation rather than medicine. As the scientific medical demand grew, so did the associations with executed criminals, grave robbing, and even murder (Burke and Hare case), that make a rich vein for writers, all too tempting then to spice it up, in a way that is ultimately disrespectful to the donors and those who care about them, and thereby also sending a negative message to students.

Access to drugs that are still under investigation for patients, especially those with cancer, is a growing topic. The opportunity to participate in clinical trials is increasingly seen as part of the normal treatment repertoire when existing evidencebased established treatment protocols have been exhausted. Bunnick and Aarts (2021) present this study of doctors in The Netherlands that examines the attitudes of Dutch physicians to compassionate "expanded" drug access for those who cannot enter clinical trials. The findings suggest that the application processes can be difficult and that, as the results are often negative, false hope is engendered and issues of risk and side effects being considerable.

At the Journal of Bioethical Inquiry, we aspire to have a global outlook, and we are pleased to publish three papers from an Islamic perspective.

The Chinese case of gene-editing for two baby girls to be HIV resistant by scientist He Jiankui sparked a very big international reaction. Isa (2021) from Malaysia analyses this case against the Islamic principle of Maslahah (literally bringing about a good outcome) and finds that it is inconsistent with sharia law and therefore not permitted. Indeed, it seems that the international scientific community thought the same.

Rattani (2021) argues that Islamic bioethical articles should adhere to accepted rules of evidence and argumentation, with particular regard to scriptural quotes and statements by scholars. The nature of authority is questioned, and presentation of statements without further critical deconstruction or argumentation is discouraged. The author encourages an open and lively exchange in the growing field of contemporary Islamic bioethics that allows the rich and diverse religious tradition to inform secular bioethics. This can only happen when religious inputs are subject to the same academic rigor as the secular field.

Obeidat and Komesaroff (2021) report on a study of thirty-eight doctors in four Jordanian hospitals inquiring about their views and experiences of clinical ethics. They found that whilst there was considerable support for certain western bioethical principles, such as diversity, there was also a need to balance this with Islamic principles. This study and the two previous papers happily lend weight to the view that dialogue is possible, and necessary, between the world's religious traditions and secular bioethics and that they can mutually nourish each other. In the west, bioethics often seems to be at odds with its historically dominant Judaeo-Christian traditions, but in other parts of the world this is not always the case. While we would hope that there was general support for the UN Declaration of Human Rights as a basis for ethical conduct, the western primacy of individual autonomy in all things and above all things has to be blended and bent to fit the contemporary situations in countries where the local tradition must be accommodated and maybe sometimes moulded over time.

In our legal Recent Developments column, Porceddu and Bhatia (2021) report on a ruling in New South Wales (Lee (a pseudonym) v Dhupar [2020] NSWDC 717), about a failed tubal ligation. The court ruled that the cost of raising the child that resulted from a negligent tubal ligation could not be recovered in damages but psychological and other harms to the mother, despite a healthy birth, could be.

As this issue shows, ethics is a process and a conversation. In moving away from a Hippocratic oath as basis for medical ethics in 2021 and beyond, it would be sad if the better angels of medical history that have flowed though it and from it were lost. In particular the notion of a sense of virtue, and moral standing, and of practitioners at least seeing the philosophical side of the practice of medicine, without actually being philosophers themselves. This is probably the role of bioethics, and a truly Hippocratic one at that, 
so the oath might go but the tradition lives, with all of us?

\section{References}

Bunnick, E.M., and N. Aarts. 2021. The role of physicians in expanded access to investigational drugs: A mixed-methods study of physicians' views and experiences in The Netherlands. Journal of Bioethical Inquiry 18(2). https:// doi.org/10.1007/s11673-021-10090-7.

Courtwright, A.M., K.S. Erler, J.I. Bandini, et al. 2021. Ethics Consultation for Adult Solid Organ Transplantation Candidates and Recipients: A Single Centre Experience. Journal of Bioethical Inquiry 18(2). https://doi.org/10.1007/ s11673-021-10092-5

Fiddes, P.J., and P.A. Komesaroff. 2021. Hidden in plain sight: The moral imperatives of Hippocrates' first aphorism. Journal of Bioethical Inquiry 18(2). https://doi.org/10. 1007/s11673-021-10097-0

Haining, C.M., L.A. Keogh, and L.H. Gillam. 2021. Understanding the reasons behind healthcare providers' conscientious objection to voluntary assisted dying in Victoria, Australia. Journal of Bioethical Inquiry 18(2). https://doi. org/10.1007/s11673-021-10096-1.

Hempton, C., and C. Mills. 2021. Constitution of "the already dying": The emergence of voluntary assisted dying in Victoria. Journal of Bioethical Inquiry 18(2). doi: https://doi. org/10.1007/s11673-021-10107-1.

Isa, N.M. 2021. Human germline gene editing from Maslahah perspective: The case of the world's first gene edited babies. Journal of Bioethical Inquiry 18(2). https://doi. org/10.1007/s11673-021-10101-7.

McLachlan, H.V. 2021. Exploitation, criminalization, and pecuniary trade in the organs of living people. Journal of Bioethical Inquiry 18(2). https://doi.org/10.1007/ s11673-021-10091-6.

Obeidat, A.S., and P.A. Komesaroff. 2021. Clinical ethics from the Islamic perspective. Journal of Bioethical Inquiry 18(2). https://doi.org/10.1007/s11673-021-10108-0.

Perez-Bret, E., P. Jaman-Mewes, L.M. Quiroz. 2021. Reflective learning of palliative care by secondary healthcare and sociosanitary students using two videoclips on the experience of Cameron Duncan: "DFK6498" and "Strike Zone." Journal of Bioethical Inquiry 18(2). https://doi.org/10. 1007/s11673-021-10093-4.

Porceddu, L., and N. Bhatia. 2021. Lee (a Pseudonym) v Dhupar [2020] NSWDC 717: Failed Sterilization: Should a Healthy Child be Considered a "Compensable Injury"? Journal of Bioethical Inquiry 18(2). https://doi.org/10. 1007/s11673-021-10105-3

Rattani, A. 2021. A critique of contemporary Islamic bioethics. Journal of Bioethical Inquiry 18(2). https://doi.org/10. 1007/s11673-021-10098-z.

Stephan, C.N., and W. Fisk. 2021. The dubious practice of sensationalizing anatomical dissection (and death) in the humanities literature. Journal of Bioethical Inquiry 18(2). https://doi.org/10.1007/s11673-021-10095-2.

Stuhmcke, A. 2021. Reframing the Australian medico-legal model of infertility. Journal of Bioethical Inquiry 18(2). https://doi.org/10.1007/s11673-021-10094-3.

Winters, J.P., F. Owens, and E. Winters. 2021. Evaluating an adolescent's decision-making capacity whilst in the harsh world of detention. Journal of Bioethical Inquiry 18(2). https://doi.org/10.1007/s11673-021-10099-y.

Publisher's Note Springer Nature remains neutral with regard to jurisdictional claims in published maps and institutional affiliations. 